DOI: $10.22363 / 2312-9182-2019-23-2-509-522$

\title{
Mode in Arabic-English Translation: with Reference to the Quran
}

\author{
Ibrahim Najjar, Soh Kwee, Thabet Abu al-Haj \\ University of Malaya \\ University Str., Kuala Lumpur, 50603, Malaysia
}

\begin{abstract}
A rhetorical question has the form of a question but does not perform its function, i.e. does not seek any information but rather, is used to give a specific or rhetoric function such as denial, assertion, testing, equalization and negation. The present study investigates the two English translations that were used in the translation of the Quranic rhetorical questions. In a nutshell, this is a comparative study that aims to discover if the grammatical shifts that had occurred in the two English translations would have an effect on the denial, assertion, testing, and equalization and negation modes of the Quranic rhetorical questions. For this purpose, we had adopted the register theory of Halliday and Hassan (1985) as well as the translation shifts of Catford (1965) in the comparison of the two English translations, namely the Koran Interpreted that was authored by Arberry (1955) and the Noble Quran: English translation of the meanings and commentary as transcribed by al-Hilali and Khan (1996). According to the analyses, the occurrence of grammatical shifts between the two translations had in fact affected the mode of the ST rhetorical questions, their rhetorical meanings and consequently, issues on mode sustenance. Therefore, it can be said that the register theory of Halliday and Hassan (1985) had been a beneficial tool used in the analysis of the translation process.
\end{abstract}

Keywords: Function, Quran, mode, register, rhetorical questions, shift

\section{For citation:}

Najjar, Ibrahim, Soh Kwee, Thabet Abu al-Haj (2019). Mode in Arabic-English Translation: with Reference to the Quran. Russian Journal of Linguistics, 23 (2), 509—522. doi: 10.22363/2312-91822019-23-2-509-522.

\section{Модальность высказывания в переводе Корана на русский язык Ибрахим Наджар, Со Би Кви, Табета Абу Аль-хаи \\ Университет Малайзии \\ University Str., Куала-Лумпур, 50603, Малайзия}

\begin{abstract}
Аннотация
Риторический вопрос имеет такую же форму, что и обычный вопрос, но выполняет иную функцию: вместо запроса информации он может выражать опровержение, утверждение, оценку, приравнивание или отрицание. В настоящей работе рассматриваются способы передачи риторических вопросов в двух переводах Корана на английский язык. Другими словами, это сопоставительное исследование, цель которого - определить, приводят ли грамматические изменения риторических вопросов
\end{abstract}


в двух английских переводах Корана к изменению модальности опровержения, утверждения, оценки, приравнивания и отрицания. Исследование опирается на теорию регистров М.А.К. Хэллидея и Р. Хасан (1985) и теорию переводческих сдвигов Дж. Кэтфорда (1965). В качестве материала исследования используются выдержки из Корана, а также два английских перевода Корана: “The Koran Interpreted by Arberry" (1955) и "The Noble Quran: English translation of the meanings and commentary by al-Hilali and Khan" (1996). Проведенный анализ свидетельствует о том, что грамматические изменения риторических вопросов в двух переводах приводят к изменению их модальности и, соответственно, их функции. Эти грамматические изменения различного уровня и типа представляют серьезную проблему с точки зрения сохранения модальности при переводе. Показано, что теория регистров Хэллидея и Хасан (1985) является удобным инструментом в процессе перевода.

Ключевые слова: функиия. Коран, регистр, риторический вопрос, сдвиг

\section{Для цитирования:}

Najjar, Ibrahim, Soh Kwee, Thabet Abu al-Haj. Mode in Arabic-English Translation: with Reference to the Quran // Вестник Российского университета дружбы народов. Серия: Лингвистика = Russian Journal of Linguistics. 2019. T. 23. No 2. C. 509-522. doi: 10.22363/2312-9182-201923-2-509-522.

\section{INTRODUCTION}

The rhetorical question is a visible notion that exists in all languages, where according to Siemund (2001:1015), "can be found in all languages of the world, and they also appear to be functioning in a comparable manner". Hackstein (2004:167) had also emphasized rhetorical questions as a cross-linguistic phenomenon that occurs in both written and oral discourse, where the rhetorical question is generally seen as a nonseeking information question. Larson (1984:257) for example, had not only explained the use of rhetorical questions for indicating interrogative grammatical forms with an intended meaning, but also to serve the speaker's subtle purpose in commanding, requesting or emphasizing a particular point (Larson 1984:257) or as described by IIie (1994:130), "heard as questions and understood as statements". Abioye (2011:291) had also mentioned rhetorical question as being a type of figure of speech that comes in the form of a question, but is used for its persuasive effect, where although the rhetorical question and the seeking-information question had shared the same syntactic structure, each however, had served a different purpose. As such, rhetorical questions had attracted a great deal of attention from the scholars because of the significant role it plays in languages. In Arab, rhetorical questions had been extensively studied by both the ancient and modern scholars alike because of its wide occurrence in the Holy Quran. In Arabic, "rhetorical question" is known as "istfham balagi" "استفهام البلاغي", which means interrogation, a statement that is formulated as a question, but has another connotation.

According to Ranganath et al. (2016:1), a rhetorical question is not one that conveys a message or meaning in an explicit way, but rather, a question that contains an implicit connotation. This was also confirmed by Bhattasali et al. (2015:743), where he had stated not only the words used in the context of the question as strong clues for understanding its message and the deviation of the actual meaning from its original form, the question would also be regarded as rhetoric or otherwise by considering the appearance of its negative polarity context. 
As for translation-wise, Larson (1974) had emphasized the importance of considering the situational context of the rhetorical question by further stating the significance of "how the communicative situation and the attitude of the speaker relate to the grammatical forms used" (1974:14) so that it would provide "a more careful analysis of the ST for translation purposes." This was also corroborated by al-Malik (1995) and el-Sa'adany (2010), where they had confirmed the importance of taking the situational context, particularly its religious translation, into consideration.

Translation shifts are inevitable during the process of translation and is an issue that is often dealt with by different theorists (Catford 1965, Vinay and Darblent 1955/1995). While translation shifts might sometimes be valuable to the translated text, it may however, lead to certain issues in the source text, where according to Wills (1982:71), the changes of a situational context will cause "changes to inevitably take place in the linguistic texture. Conversely, if a shift is carried out on the linguistic level, this context of situation will also change". Hence, the aim of this study is to discover if the occurrence of grammatical shifts in the two English translations had affected the mode of the translated rhetorical questions.

\section{ARABIC RHETORICAL QUESTIONS}

By considering the inclusion of rhetorical questions, many Arab grammarians and rhetoricians had since attempted to clarify the different meanings and constructions of the term "interrogation". Etymologically speaking, the word "al-Istifham" /interrogation/ is not only a verbal noun that is derived from the verb "Istafhama", which means "asking for understanding" (Bofama 2014:11), but is also related to the noun "al-Fihim" /understanding that denotes "understanding things by heart" (al-Fayroz Abadi 2001:1056). For this reason, the Arab grammarians had defined interrogation as interrogating the listener of things that the interrogator does not know (al-Soyoti 1985, Ibn Fares 1998).

Most of the Arab grammarians however, had noticed the deviation of interrogation from its original meaning, where it had given rise to the rhetorical question that is known as "al-Istifham al-Balagee". As mentioned earlier, while the "al-Istifham" is a verbal noun that is derived from the verb "Istafhama", "al-Balagee"/rhetorical on the other hand, is an adjective that is constructed from the noun "al-balagah". In this sense, "Istifham Balagi" is not only deemed to have functioned as a noun phrase at a syntactic level, but had also acted as a stylistic device with certain functions, where in this case, had been the denial function of the rhetorical questions as mentioned by Sibawayh (cited in Aida 2012:25), the most well-known Arabian linguist.

For this reason, many Arab rhetoricians had adopted some of the progress made by the grammarians and studied these interrogations or questions from a rhetorical point of view. They however, had considered the Arabic interrogation as not reflecting its true meaning, but rather, possesses some other underlying meanings known as rhetorical interrogation. These rhetorical meanings or functions are not arbitrary generated but is formed by certain factors such as the context of the question, the speaker's intention, the relationship between the speaker and the listener and also the occasional structure of the question that was used (al-Balakhi 2007:54). 


\section{FUNCTIONS OF ARABIC RHETORICAL QUESTIONS}

The functions of rhetorical questions vary from one scholar to another. While some scholars like Ibn Khalawyh (1996:326) may consider rhetorical questions as having 4 functions, there may be others who had believed otherwise. This had therefore prompted many Arab grammarians and rhetoricians to attempt distinguishing the different functions of the rhetorical questions by looking at both the context and structure of the said question. There were also more recent Arabian scholars who had deliberated on the functions of rhetorical questions. In his study, Foda (1953) had specified eleven primary and fourteen secondary functions for such questions, where the differences were due to the speaker, the addressee as well as the state of the addressee.

In fact, although there had been numerous functions of rhetorical questions mentioned by the Arabian scholars, the Arab rhetoricians and grammarians however, had only discovered a common understanding of just over ten prominent functions of the rhetorical questions (Rajdal, 2013). As for the other functions, these were considered secondary and were further divided into ten primary sub-categories to include denial, assertion, exclamation, order, equalization, wish, negation, test, augmentation and suspense. In this study, only the denial, assertion, negation, equalization and the test functions had been focused on with their brief explanation as described below:

1. Denial: Denying means the refusal of admitting or acknowledging something that had actually happened. According to al-Balakhi (2007:101), denial is a means that is used by a speaker for creating awareness in the listener and the realization that he/she had committed a mistake, lied or on the pretext of performing a task. As such, denial can be consisted of two types:

1.1. Denial indicates rebuke, where it not only involves rebuking a person about incidents that should not have happened in the past, but also on events that is occurring at the current moment and its possible future occurrences (al-Balakhi 2007:103).

1.2. Denial indicates refutation, where it involves refuting what is not the truth and legitimate. According to Abbas (1997:194), this kind of denial is used to refute false opinions from both the past and present.

2. Assertion: to indirectly force the listener to confess on things that he/she has knowledge of (al-Ameri, et al. 2012:86, Sagir 2015).

3. Test: this question type is used for the purpose of testing the listener.

4. Negation: to negate something. Linguistically, the word negation in Arabic revolves around expulsion and the cessation of a particular issue.

5. Equalization: is regarded as a combination of both hamza "l” (a/alif) and the coordinated conjunctive "م"/am/ (or) (al-Zamakhshri, 2009).

\section{METHOD}

\subsection{Data collection}

The data from the study had originated from the Quran, where they had consisted of rhetorical questions that were associated with denial, assertion, negation and test functions. These rhetorical questions were also supplied together with the two respective 
English translations used, namely "The Koran Interpreted" and "The Noble Quran: English translation of the meanings and commentary" that were authored by Arberry (1955) and al-Hilali and Khan (1996), respectively.

\subsection{Context of situation}

In one of their studies, Halliday and Hassan (1985) had discussed the function of "register" under the situational context, where they had described the meaning of the word, sentence and text to be governed by the situational context. A situational context is deemed to be composed of field, tenor and mode variables. While field had concerned those of a subject matter and tenor as dealing with the relationship between/among the speakers, mode on the other hand, is one that is related to the written and oral construction of the language.

Language is also seen as serving three meta-functions that provide "ideational, interpersonal and textual meanings" (Halliday and Hassan, 1985), where the ideational meaning denotes the way the text had represented external reality, interpersonal meaning as describing the relations between the speakers and the listeners, while the textual meaning is regarded as dealing with the cohesion as well as the information and thematic structures of a particular language. Researchers had found a connection between these meta-functions and the register terms, which were depicted by the association shown between the field and ideational meaning, tenor with interpersonal meaning and mode to the textual meta-function. As such, it is important that the associations between these variables and the meta-functions are not ignored, but rather, are dealt with so that the differences of the situational context between any two languages can be detected. Based on the above reasons, this theory was thus adopted in studying the data of the Quran.

\subsection{Translation shifts}

In his study, Catford (1965) had examined two types of equivalence, where the formal correspondence had been described as "any TL category (unit, class, structure, etc.) that occupies as nearly as possible the 'same' place in the 'economy' of the TL, as the given SL category had occupied the SL" (1965:27), and when this type of equivalence is not achieved, the textual equivalence would then be required and is attained through "shifts". Catford (1965:49) sees the textual equivalence as textual items with "a greater overlap of situational range" that are dissimilar across cultures. To put this in a more contemporary systemic functional term, Shore (2001:259) had mentioned texts or parts of texts to be equivalent if they had functioned in the same manner as those exhibited by the SL and TL. For this reason, textual equivalence can be defined as "any observed TL text or portion of text on a particular occasion to be the equivalent of a given SL text or portion of text" (1965:159). Catford (1965) had also differentiated the two types of translation shifts as:

A-Level shift: this type refers to a concept, which is expressed grammatically in one language but is shifted into lexis in another.

B-Category shift that is consisted of:

(i) Structural shift: which can be found at "all levels of language and occurs because the ST structure had been different than those of the TT". 
(ii) Class shift: one part of speech that is shifted to another.

(iii) Unit shift: "such a shift occurs when the TL translation equivalence has a different rank compared to the SL". "Rank here refers to the hierarchical linguistic units of sentence, clause, group, word, and morpheme".

(iv) Intra-System shift: "This shift occurs when the SL and TL "possess approximately corresponding systems" but where "the translation involves selection of a non-corresponding term in the TL system".

\section{DATA ANALYSIS}

\section{Data 1 (Denial)}

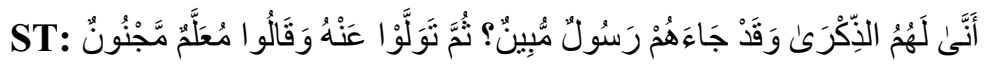

Trans: anna lahum althikra wa qad ja'hum rasulun mubinun?

TT1: How can there be for them an admonition (at the time when the torment has reached them), when a Messenger explaining things clearly has already come to them. Then they had turned away from him (Messenger Muhammad SAW) and said: (He is) one taught (by a human being), a madman! (al-Hilali and Khan)

TT2: How should they have the Reminder, seeing a clear Messenger already came to them, then they turned away from him and said, 'A man tutored, possessed! (Arberry)

\section{ST and TT1}

The denial of the ST had begun with the question noun "أنى" (anna) /how/. This lexical item was found to have three uses in Arabic, where it might ask about a place, time or the state of the condition/manner. Here, since Allah had known the natural condition of the unbelievers for refusing to believe and follow, the question noun "أنى (anna) /how/ was therefore used to describe the condition mentioned (al-Zamakhshri 2009) and the adverb "how" had been used appropriately by the translators who were aware of this purpose. In another phrase, Allah had denied them through a warning as seen in the NP "الذَّكْرَى " (al-thikra), which literally means "remember". When this was decreed into English, the TT1 had deciphered it to mean "an admonition", since the translators had wanted to demonstrate the disbelieving nature of the unbelievers.

Allah had then used a circumstantial clause (adverbial clause) that starts with the circumstantial "g" (wa)/seeing/, which had explained the reason of the unbelievers' sceptical nature on the messenger that was sent to them. Although the same structure was utilized in the TT1, it had however, used under a different purpose of "time". Therefore, changing the circumstantial "g" (wa)/seeing, since/ into the adverb of time, where in this case had been "when", had somehow distorted its actual meaning. As for the emphatic particle "قد" (qad) /verily/ that was followed by the circumstantial "و" (wa) /since/, this was to imply that a messenger had already come to them. When translated however, the adverb "already" was used instead to confirm the arrival of the messenger. The NP "رَسُولْ مُبِينِّ" (rasulun mubinun) that had appeared at the end of the circumstantial clause says that the messenger had explained everything to them. When translated, the translators had used the NP "a messenger" as referring to the "رَسُؤ" " /messenger/ and the VP "explaining everything clearly" to denote "مُّبِينّ" (mubinun), 
which in this case is an agent noun that was derived from the V "يبين" or "explains". Under this circumstance, the VP that was used to translate "explaining everything clearly" was found to have reflected the meaning accurately and hence had maintained the mode variable in TT1.

\section{ST and TT2}

The ST had started the denial with the question noun "أنى" (anna) /how/, where it is used in Arabic to inquire about a place, time and condition/manner. According to al-Zamakhshri (2009), since Allah had known the disbelievers' condition for refusing the caution given, the question noun "أنى" (anna) /how/ was therefore used for the condition purpose. In TT2, the adverb "how" was used, where it had reflected the exact meaning of this Arabic lexical item. This was then followed by the use of the NP "the reminder" in TT2 as shown in the NP "الزِّّرَزَى" (al-thikra) that was indicated by Allah's rebuff on them for not taking heed. Although the two had shared the same grammatical category, their meanings however, were found to have differed. On Allah's statement on why the people had not believed in Him although the messenger had come for them, the circumstantial clause that was used for this purpose was then started with the circumstantial "g" (wa)/since/. Although the "g" (wa) / since/ had literally meant "and", it was used instead under the circumstantial purpose. In the translation however, the translator had used the conjunction "seeing", which had served the purpose of the ST "و" (wa)/since/. As for the emphatic particle "قد" (qad)/verily/ that was followed by the circumstantial "g", it had emphasized the action expressed by the verb, which is the coming of the messenger and when translated, the adverb "already" could be successfully used to imply that a messenger had already arrived. The NP "رَسُولن مُّبينُْ " (rasulun mubinun) /a messenger explains everything/ was however, changed into a different class with the AP denoting "a clear messenger". While the NP of the ST had stated the messenger who "explains" everything had already arrived, the AP of the TT2 on the other hand, had suggested a "clear messenger" or "an obvious one had already arrived", where in this case, had not only distorted the intended meaning, but had also led to the partial distortion of the ST and its rhetorical meaning.

\section{Data 2 (Assertion)}

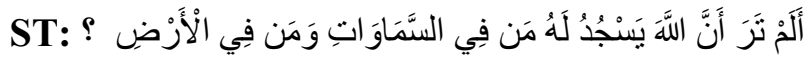

Trans: a lam tara ana Allah yasjudu lahu man fi alsamawat wa man fi alarith?

TT1: See you not that whoever is in the heavens and whoever is on the earth, and the sun, and the moon, and the stars, and the mountains, and Ad-Dawabb (moving (living) creatures, beasts) and many of many kinds prostrate themselves to Allah? (al-Hilali and Khan)

TT2: Hast thou not seen how to God bow all who are in the heavens, earth the sun and the moon, the stars and the mountains? (Arberry)

\section{ST and TT1}

The assertion function had begun with the question particle "f)" (a/alif) and was added to the negative and jussive particle of "لم" (lam) / not/ since negation is one of the features in the Arabic assertion RQ that is used to denote negate or contradiction. 
The question particle "I)" (a/alif) in Arabic had emphasized the entity that was used after it and although the imperfect verb of the jussive mood " used (Abu-Haiyan 1984), it had somehow demonstrated a perfect relevance under this circumstance. Hence, the question particle "')" (a/alif) together with the negative particle "ل" (lam) /not/ that had existed as "ألم" (a lam) was used to assert that the Prophet or the One addressed, had already known all the living beings under the sky as showing their reverence and submission to Allah. In TT1 however, the question particle " "l," (a/alif) was not used, but was instead substituted with an old English structure that began with the verb "see". While the question particle that was mentioned earlier had emphasized on the verb "تز" (tara), the translators however, had placed the emphasis on this verb "see", which was similar to that of the ST. Apart from this, the translators had also used the verb "see" along with the negation aspect of "not" as a way of providing an opposite meaning that is aligned with the ST. Despite the few differences shown from the meanings between the ST and TT1, the V in the ST " meant "know", while the word "see" that was used in the TT1 had denoted a different meaning. The beginning of the message was also observed to be negligibly affected by the different tenses of the two verbs used.

The subordinate conjunction "أََّّ" (ana)/that/ had indicated factual information as shown in the phrase "that to Allah the livings prostrate". As a way of fulfilling the meta-function of this subordinate conjunction, the translators had thus used the conjunction "that", which had functioned in the same manner as "نَّ" (ana), where the rest of the ST had ended up mentioning the places that were inhabited by the livings beings. Since the mentioning of places had been achieved under TT1, the rest of the TT1 had thus provided the same meaning as that of the ST. As a result, the mode variable was not only perfectly maintained; its rhetorical meaning was also being preserved as well.

\section{ST and TT2}

In the ST, the assertion function had begun with the question particle "'ll, (a/alif) that was added to the negative and jussive particle "لم" (lam)/not/. Since negation is one of the Arabic assertion RQ features that denotes to negate or contradicting, the question particle "f)" (a/alif) in Arabic had therefore focused on the entity that was used after it, which was expressed by the imperfect verb in jussive mood "je" (tara) /know/. Hence, the question particle "أl" (a/alif) together with the negative particle "لم" (lam)/not/ that had existed as "ألم" (a lam), had confirmed that the Prophet or the addressee already had the knowledge of every living being under the sky as demonstrating their submission and reverence to Allah. In the translation however, although the question particle "I)" (a/alif) was shifted into the verb "hast" and was combined with the negation particle of "not", the use of "hast" to render "Il" (a/alif)" was found to be well-suited in describing the said circumstance since both the "Il" (a/alif)" and "hast" had focused on the imperfect verb in the jussive mood of "تَ" (tara) /known/. While the use of "hast" was found to denote perfect relevance on the imperfect/present tense of " "ترَ" (tara) /known/, the use of negation "not" however, was found to be important for emphasizing assertion in English. Some differences were still observed between the meaning of the V "تَر" (tara) /know/ and its translated verb "seen", since the former had indicated "knowing things by heart". 


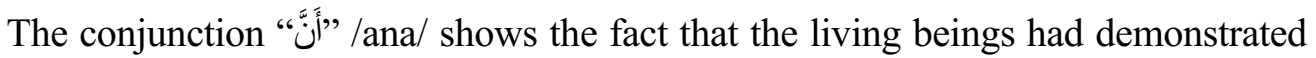
submission and reverence to Allah, but when translated, it was shifted into the adverb "how". Since the adverb "how" had indicated manner and condition, then what follows had been the way the living beings had prostrated to Allah and not the fact that they had shown reverence to Him. Moreover, the verb " "يَسْنجدُ" (yasjudu) had meant "prostrate" (Ibn-Ashur, 1984) and by using "bow" to render it had given it a different meaning and consequently, not reflecting the meaning of the actual message. For this reason, the differences had led to the partial distortion of both the mode variable as well as its rhetorical meaning.

\section{Data 3 (Testing)}

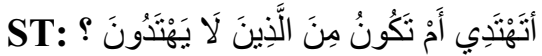

Trans: a tahtadi am takun min altheen la yahtadun?

TT1: whether she will be guided (to recognise her throne), or she will be one of those not guided. (al-Hilali and Khan)

TT2: whether she is guided or if she is of those that are not guided. (Arberry)

\section{ST and TT1}

The test function of ST had begun with the question particle "fl" (a/alif) that functions as D, where in this case, the question particle had meant "if/whether". Under this circumstance, the addresser had wanted to test the addressee, which in this case, the Queen, if she had recognized her throne. Therefore, the translators had used "whether" to replace the question particle "Il", where it had functioned as D in the testing of two items "الهداية أم عدمها" /knowing or not/ hence, maintaining the departure of the ST. It was mentioned earlier that the addresser had wanted to test the addressee if she had

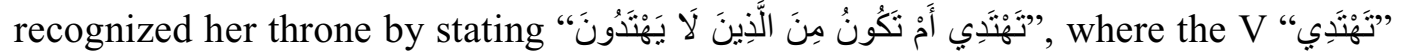
(tahtadi), which had meant "know or recognize" is in the active form, but was changed to the VP passive of "will be guided" in the translated version instead, hence, affecting

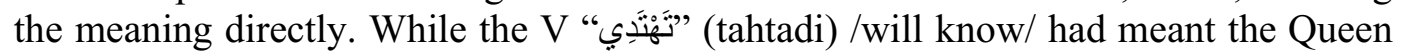
or the addressee will have the knowledge of her throne, the message from TT1 on the other hand, had implied that someone will lead her to know or recognize her throne.

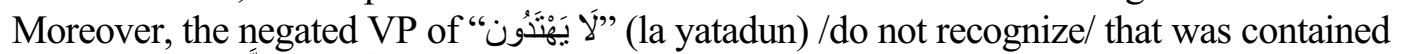

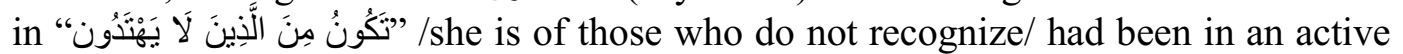
imperfect form, while its translated VP version of "not guided" was found to be in the passive form. Again, the occurrence of a level shift had not only changed the meaning of the information that was provided by the ST in TT1, the mode variable was also partially affected as well.

\section{ST and TT2}

In the ST, the testing function was confirmed by the question particle "fl" (a/alif) that had functioned as a D. Since it was used for testing, the translator had used the conjunction "whether", which had also served the same function as D in providing the same meaning for the "ll" (a/alif) testing. The ST tests of between two things /knowing or not/

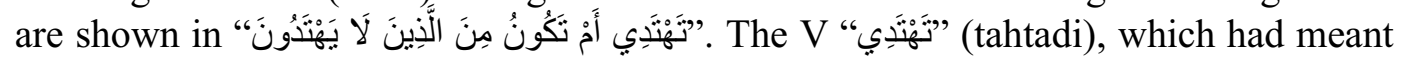


"knows or recognize it" and in the active form, was found to have been changed into the VP "is guided" by the translator instead and had resulted in a total distortion

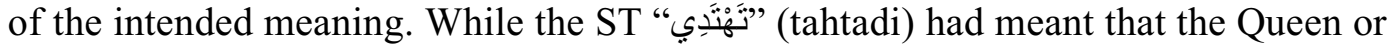
the addressee, will have the knowledge of her throne, the meaning that was suggested in TT2 however, had implied someone who will lead her to recognize her throne.

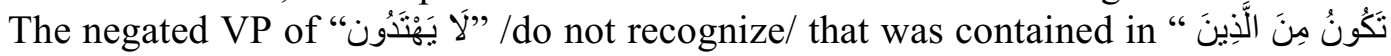
" لَ يَهْنَدُون /she is of those who do not recognize/ was found to be connected with the V "ن" (tahtadi) that was presented as the negated VP of "are not guided". However, the change of TT2 to the passive form from the active structure of the VP in the ST had once again altered the meaning of the ST, thus partially affecting both the mode variable and the rhetorical meaning of the ST.

\section{Data 4 (Negation)}

\section{ST: وَمَنْ أَحْسَنُ مِنَ المَّهِ صِبْغَلَ}

Trans: wa man ahsanu min Allah Sibghah?

TT1: And which Sibghah (religion) can be better than Allah's? (al-Hilali and Khan)

TT2: and who is there that baptizes fairer than God? (Arberry)

\section{ST and TT1}

The ST question begins the negation by stating no one can provide the people with a religion better than Allah by using "وَمَنْ أُحَسْنُ", which had meant "no one is better". While the ST had concentrated on the one negated, the structural change that had occurred in the TT1 on the other hand, had started with "and which Sibghah (religion)?" instead, where the "صِبْغَ" (Sibghah) that was written at the last part in the ST was moved to the beginning portion of the TT1. As a result, the TT1 translators had switched the concentration from the "one" to "Sibghah" (religion) and by negating the "صِنْغَغَ" (Sibghah)/religion/ and not the "one", the mode that was situated in the beginning part of the ST was therefore disregarded. The PP of the ST "مِنَ اللَّه صِنْغَفَّ", where it had meant /than Allah's religion/ was found to have completed the negation by stating that no one can provide the people with a religion better than Allah as denoted by the PP "than Allah's" that was preceded by "can be". Although the meaning concerning Allah and His religion had been reflected in the PP, it was however, not preserved in the beginning portion of the ST and consequently, led to a partial distortion of both the mode variable and its rhetorical meaning.

\section{ST and TT2}

Although the ST "وَ" had meant "no one", the translator had begun the TT2 by rendering the question N " noun, the translator had wanted to focus on the negated person that was implied in the ST. The N "حَحَّنَ" (ahsanu) in the ST, which had come directly after the question noun had implied "better" or in other words, "no one is better" and when rendered, contained both the class and structural grammatical shifts. Apart from the switch of the location, the term was also substituted by the "fairer" adjective, which has a close meaning

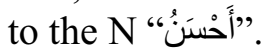




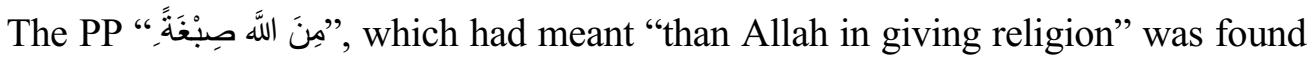
to have changed to a different meaning as a result of using the VP "baptizes fairer than Allah", where the last item of the N "صَبْغَة" /Sibghah/ in the ST was changed into a different class of V "baptizes" and yielded a different meaning. While "صِنْغَغَّ" /Sibghah/ denotes the spiritual religious beliefs provided by Allah as well as a representation of Islam, baptism on the other hand, is a Christian ritual that is performed by the ordained ministers on the Christian believers. As a result of these changes, the meaning in the last part of the ST had been somehow overlooked, thus leading to the partial distortion of both the mode variable and its rhetorical meaning.

\section{Data 5 (Equalization)}

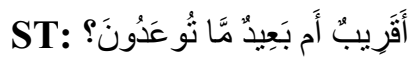

Trans: a qarib am ba'ed ma tu'adun?

TT1: whether that which you are promised (i.e. the torment or the day of resurrection) is near or far. (al-Hilali and Khan)

TT2: whether near or far is that you are promised. (Arberry)

\section{ST and TT1}

The function of equalization in terms of interrogation was found to be embedded in the "أَقَريبُ أَم بَعِيديد" (a qarib am ba'ed) core structure of the ST. This structure had begun with the question particle "I)" (a/alif) or in other words, the particle of equalization to indicate the equalization of two items in the ST. This particle of equalization that functions as D had maintained its category with the use of "whether" since this conjunction had been the only choice used by the translators to introduce a question with alternatives. The clause "قَرِيبُ أَم بَعِيد" had contained two equalized items that were connected by the conjunction "أم" /or/ meaning / far or near/ and were changed from NP to the AP "near or far" to denote a more suitable meaning. The relative clause of " (ma tu'adun) /what you are promised, which means the promised punishment that will be delivered by Allah on the disbelievers was found to have reflected in the TT1 of "which you are promised". By sustaining the meaning in the structure, both the mode variable and the rhetorical meaning of the ST were found to have been preserved in TT1.

\section{ST and TT2}

As mentioned earlier, the ST had performed the equalization function by means

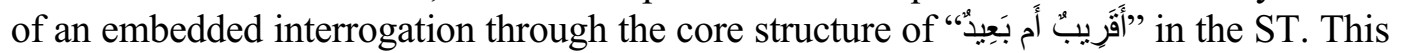
structure had begun with the particle of equalization "fl" (a/alif) and was added to the NP "قَرِيبُ أَح بَعِيد"، to not only indicate /near or far/, but also to equalize between the two items

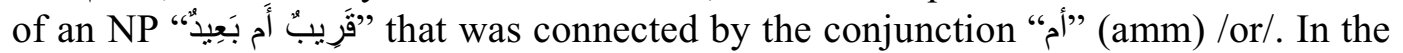
translation, the particle of equalization "I)" was rendered as "whether", while the NP "قرَرِيبٌ أَم بَعِيد", which is related to the two equalized items that are connected by the conjunction "إ" /or/, was changed to the AP "near or far". The particle of equalization was also found to have served its grammatical and semantic functions as indicated by the translated "whether", which had functioned in the same way as D by providing the

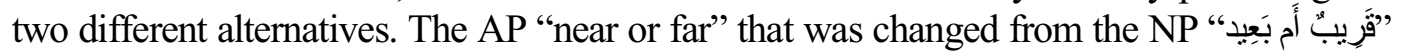


and the same structure that was used in the TT2 of "that you are promised" from the relative clause "مَّانُوَعَدُونَ" of punishment of Allah were found to have served the intended meaning and had preserved both the mode variable as well as the rhetorical meaning of the ST.

\section{CONCLUSION}

This study had compared two English translations of the Quranic rhetorical questions, where the main objective had been to discover if the occurrence of grammatical shifts during the translation process had affected the mode of the ST Quranic rhetorical questions. From the above analyses, the grammatical shifts that had occurred during the translation process were not only found to have greatly affected the mode of the ST rhetorical questions, but also on the rhetorical meanings as well. According to the analyses, the level and class changes were also discovered to be the principal causes for distorting the mode of the ST rhetorical questions.

Although there had been no major differences observed between the two translations, the mode variables from the two translations were found to have experienced a slight distortion from the intended meanings. In spite of this, the translation that was conducted by al-Hilali and Khan (1996) was discovered to have a better interpretation of the mode variable than those of the Arberry's because of the higher focus placed on the Quranic interpretation (1955).

(C) Ibrahim I.I. Najjar, Soh Bee Kwee, Thabet Abu al-haj, 2019

\section{REFERENCES}

Abioye, Taiwo (2011). Preference for rhetorical questions as an index of textual message effectiveness. International Journal of Humanities and Social Science. V. 1. No. 1.

Arberry, Arthur John (1955). The Koran Interpreted: London: Allen \& Unwin.

Bhattasali, Shohini, Cytryn, Jeremy, Feldman, Elana, \& Park, Joonsuck (2015). Automatic identification of rhetorical questions. In $A C L$.

Catford, John Cunnison (1965). A Linguistic theory of translation. London: Oxford University.

Hackstein, Olav (2004). Rhetorical questions and the grammaticalization of interrogative pronouns as conjunctions in Indo-European. In Adam Hyllested, Anders Richard Jørgensen, Jenny Helena Larsson et Thomas Olander (eds.), Per Aspera Ad Asteriscos, Studia Indogermanica in honorem Jens Elmegård Rasmussen sexagenarii Idibus Martiis anno MMIV.

Halliday, Michael Alexander Kirkwood, \& Hassan, Ruqaiya (1985). Language, Context and Text: Aspects of Language in Social - Semiotic Perspective. Waurn Ponds, Victoria: Deakin.

Ilie, Cornelia (1994). What else can I Tell you? A Pragmatic study of English rhetorical questions as discursive and argumentative acts. Stockholm, Almqvist \& Wiksell International.

al-Hilali, Muhammad Taqi-ud-Din, \& Khan, Muhammad Muhsin (1996). The Noble Qur'an: English Translation of the Meanings and Commentary. King Fahad Complex for the Printing of the Holy Quran. Madinah, K.S.A.

Larson, Mildred (1974). The communicative situation and rhetorical questions. Notes on Linguistics, $9,14-18$.

Larson, Mildred (1984). Meaning-Based Translation: A Guide to cross-language equivalence. New York: University Press of America. 
al-Malik, Fahad M. (1995). Performative utterances: their basic and secondary meanings with reference to five English translations of the meanings of the holy Qur'an. Unpublished PhD Thesis, Durham University, UK.

Ranganath, Suhas, Hu, Xia, Tang, Jiliang, Wang, Suhang, \& Liu, Huan (2016). Identifying rhetorical questions in social media. In ICWSM.

el-Sa'adany, Kamel Abdelbadie (2010). Function of interrogations in the Hadith: a sociolinguistic study. Retrieved from www.docplayer.net.

Siemund, Peter (2001). Interrogative constructions, In Haspelmath et al. (eds.). Language Typology and Language Universals. Berlin: Mouton de Gruyter, PP.1010-1028.

Shore, Susanna (2001). "Teaching Translation" in exploring translation and multilingual text production: beyond content, Erich Steiner and Collin Yallop (eds.), Berlin: Mouton de Gruyter, $249-76$.

Vinay, Jean-Paul, \& Darbelnet, Jean (1995). Comparative Stylistic of French and English: A Methodology for Translation. Amsterdam: John Benjamins, The Netherlands.

\section{Arabic references}

Abbas, Fadhil (1997). Albalagha fonunha wa afnanuha: ilmualm 'ani. Daru alfurqan.

Abu-Haiyan, Muhammad (1993). Tafsir albahar almuhit. Dar alkutub alilmiah, Beirut, Lebanon.

Aida, Nagish (2012). Uslub alistifham fi alahadith alnabuyah fi riadh alsalhin: dirasa nahuwih balaghya. Unpublished M.A dissertation, Moluod Mu'amari University, Algeria.

al-Balakhi, Muhammad (2007). Asalyib al-istifham fi al-bahith al-balaghi wa asraruha fi al-quran alkarim. Unpublished PhD Thesis, the international Islamic University, Pakistan.

al-Amri, Shakir, Khursindi, Mahmoud, \& Tarhami, Sumayah (2012). Tajahul al-arif fi alquran: ist'malatuhu wa aghrathuhu albalaghya. Majalat dirasat alogat alarabya wa adabuha.

Bofama, Sarah (2014). Uslub alistifham fi qisat Ibrahim. Dirasah nahuwya balaghya. Unpublished M.A dissertation, Abdul Qadhir University, Algeria.

al-Fayroz Abadi, Muhammad (2001). Alqamos almuhit. Dar ihya'a alturath alarabi. Beirut. Lebanon.

Foda, AbdulAlim (1953). Asalib alistifham fi al-Quran. A Published PhD Thesis, Cairo, Dar-alsha'ab.

Ibn Ashur, Muhmmad Al-Tahir (1984). Tafser al tahrir wa altanwir. Aldar at-tunisya llnashir.

Ibn Fares, Ahmad (1997). al sahibi fi fiqh alugah alarabya wa masa'iluha wa sunan alArab fi Kalamuha. Dar al Kutub alilmyah.

Ibn Khalawyh, Hussain (1996). Alhujah fi alqira'at alsaba'a. Beirut. Mu'asasat elrisalah.

Rajdal, Halimah (2013). Balaghat alistifham wa dalalatuhu fi al-Quran alkareem. Unpublished M.A dissertation, Wahran University, Algeria.

Sagir, Sa'diyah (2015). Muqaraba Dalaliya fi Ma'ani al-Istifham al-Balaghya. Biblid.

al-Soyoti, JalalAldin (1985). Al-ishbah wa al-nathair fi alnahu. Altaba alwla. Muasasat Risalit Beirut.

al-Zamakhshri, Mahmoud (2009). Tafseer al-kashaf an haqaiq altanzeel wa oyon alaqaweel fi wujuh alta'weel. Dar almarifa.

\section{Article history:}

Received: 10 December 2018

Revised: 26 February 2019

Accepted: 23 March 2019 


\section{История статьи:}

Дата поступления в редакцию: 10 декабря 2018

Дата принятия к печати: 23 марта 2019

\section{Bionotes:}

IBRAHIM I.I. NAJJAR is Ph.D. in Translation Studies, Faculty of Languages and Linguistics, University of Malaya. His area of research includes: translation theory and practice and systemic functional linguistics.

Contact information: e-mail: ibrahim99@siswa.um.edu.my

SOH BEE KWEE is Ph.D., Assistant Professor, Faculty of Languages and Linguistics, University of Malaya. Her research interest includes translation studies and contrastive text linguistics.

Contact information: e-mail: bksoh@um.edu.my

THABET ABU AL-HAJ is Ph.D., Associate Professor, Department of the Quran and Hadith, Academy of Islamic Studies, University of Malaya. His research interest includes: Quranic Studies, Hadith Studies and Translation studies.

Contact information: e-mail: thabet2012@um.edu.my

\section{Сведения об авторах:}

ИБРАХИМ НАДЖАР - кандидат филологических наук, преподаватель факультета иностранных языков и лингвистики, университет Малайзии. Сфера научных интересов: теория и практика перевода, системно-функциональная лингвистика.

Контактная информация: e-mail: ibrahim99@siswa.um.edu.my

СО БИ КВИ - кандидат филологических наук, старший преподаватель факультета иностранных языков и лингвистики, университет Малайзии. Сфера научных интересов: теория и практика перевода, контрастивная лингвистика текста.

Контактная информация: e-mail: bksoh@um.edu.my

ТАБЕТА АБУ АЛЬ-ХАИ - кандидат филологических наук, доцент кафедры Корана и Хадиса, Академия исламских исследований, университет Малайзии. Сфера научных интересов: изучение Корана и Хадиса, теория и практика перевода.

Контактная информация: e-mail: thabet2012@um.edu.my 